\section{Study on the association between earnings management and value relevance based on the reporting method used for operating cash flows}

\footnotetext{
Maria Carmen HUIAN,

"Alexandru loan Cuza" University of lasi, Romania, Faculty of Economics and Business Adminstration,

E-mail:maria.huian@uaic.ro

Marilena MIRONIUC,

"Alexandru loan Cuza" University of lasi, Romania, Faculty of Economics and Business Adminstration,

E-mail: marilena@uaic.ro

Mihaela CHIRIAC,

"Alexandru loan Cuza" University of lasi, Romania, Faculty of Economics and Business Adminstration, E-mail:mihaela.chiriac13@gmail.com
}

\section{Albstract}

This paper analyses the association between earnings management and value relevance of accounting information, for a number of 556 observations from a sample of 65 companies listed on the Bucharest Stock Exchange during a 10 year period: 2006-2015. Sampled companies are classified according to the method used for the reporting of operating cash flows. Findings confirm that entities using the indirect method have a higher level of discretionary accruals and are more tempted to opportunistically increase their earnings. As far as value relevance is concerned, results show that participants on the Romanian capital market place more weight on the information reported by entities experiencing higher levels of discretionary accruals.

Keywords: accounting quality, earnings management, value relevance, cash flows

JEL Classification: M41, M10

To cite this article:

Huian, M.C., Mironiuc, M. and Chiriac, M. (2018), Study on the association between earnings management and value relevance based on the reporting method used for operating cash flows, Audit Financiar, vol. XVI, no. 1(149)/2018, pp. 101-110, DOI: 10.20869/AUDITF/2018/149/002

To link to this article:

http://dx.doi.org/10.20869/AUDITF/2018/149/002

Received: 06.11.2017

Revised: 08.11.2017

Accepted: 09.11.2017 


\section{Introduction}

The common saying "information is power" is more accurate than ever in the current economic environment. The annual financial statements represent a crucial source of comprehensive quantitative information that plays an important role in the decision-making process. The quality of information contained in these financial reports influences the quality of current decisions, the perspective of making decisions and, implicitly, the results obtained after the decisions are made.

A central topic of the economic research dealing with accounting quality is the extent to which managers modify the reported earnings for their own benefit (Beneish, 2001). If managers are remunerated on the basis of the reported results, they will be tempted to apply techniques that will allow them to increase their personal benefits. In addition, as accounting rules allow alternatives, estimates and judgments, managers have a degree of flexibility in choosing the reporting solution best suited to the entity or their interests, without breaching any legal regulations. This technique, called earnings management (EM), has been a long-debated topic. Hunton, Libby and Mazza (2006) show that more transparent financial reporting reduces the likelihood that managers engage in EM strategies. Financial statements are considered transparent only when interested parties have access to all relevant information [...] in a timely manner (Vladu, Amat and Cuzdriorean, 2014).

Another important topic investigated in accounting quality literature is related to the usefulness of accounting information to investors. This dimension is known as value relevance. From the investors' perspective, accounting information is deemed value relevant when it helps assessing stock prices or returns. A significant number of studies try to answer this question: is accounting information relevant to investors that aim to estimate company value?

Our paper combines the two dimensions of accounting quality: accrual EM and value relevance. First, it investigates whether companies using the indirect calculation method for the cash flows from operations (CFO) are more likely to use EM practices than those applying the direct method. To achieve this, the sampled firms are separated in two groups based on the CFO reporting methods. As CFO is more objective and harder to manipulate if it is determined under the direct method
(Mironiuc, 2006), we expect less EM practices at companies applying it. Findings confirm that entities using the indirect method are more tempted to opportunistically increase their earnings.

The second part of the study attempts to identify the association between EM and value relevance of accounting numbers by using the price model. Previous research has shown that opportunistic behaviour of management alter the reporting value of accounting information (Callao, Cimini and Jarne, 2016). Our results contradict it as investors in the Romanian market find information reported by entities which experience high level of discretionary accruals to be more informative.

Our paper differs from others through a series of features: i) it addresses the EM issue in terms of CFO reporting method. Therefore, the study identifies a different setting in which EM may occur; ii) it extends literature about emerging countries, the case of Romania, analysing not only the existence of EM strategies, but also their impact on the usefulness and informative potential of the accounting figures; iii) it does not use the individual year's estimation for the selected EM model as it is based on a small number of observations provided by the Romanian market which could generate contradictory results. To avoid this, it estimates the empirical model by pooling the observations across all 10 years of study.

The rest of the paper is organized as follows: section 1 deals with the literature review and the development of research hypotheses, section 2 presents the research methodology, section 3 describes the data used and the corresponding statistics, while section 4 discusses the results. Section 5 concludes the paper.

\section{Literature review and development of hypotheses}

The literature review reveals that there many definitions of EM. Healy and Wahlen (1999) assert that EM occurs when managers use judgement in financial reporting and structuring transactions in order to alter financial statements to either mislead investors about the economic performance of the company or to influence the contractual results that are conditional on achieving a certain level of accounting numbers. Roychowdhury (2006) states that EM is the deviation from the usual practices generated by the management's motivation to 
give investors the belief that the financial objectives were met in the normal course of business.

All definitions underlie the deliberate change in the company's performance made to achieve predefined profit targets. Generally, EM has a negative connotation because only certain users of accounting information benefit from it. Moreover, managers shape financial reporting in ways that allow them to hide the real performance of the company by creating artificial records or by overusing estimates. EM practices are deemed positive if and only if they are used by managers to improve the welfare of all stakeholders, increase investor confidence and allow for reliable financial numbers, without breaking any legal requirement.

According to Gunny (2010), EM can be classified into two categories: accruals management and real activities manipulation. First category involves the selection of certain accounting methods when disclosing accruals in the financial statements, in a deliberate attempt to achieve the desired level of earnings, while real activities manipulation means modifying the timing and structuring of normal activities of the company in an effort to accomplish certain objectives.

There are two types of accrual-based EM: opportunistic and informative (Obigbemi et al., 2016). Opportunistic $\mathrm{EM}$ is driven by management compensation (e.g. increasing incentives such as bonus and commission), therefore it is used by managers to achieve personal objectives rather than organizational ones. The informative type, considered to bring gains to shareholders, is aimed at increasing the value of the company by revealing to investors managers' expectations about the firm's expected cash flows. In a study conducted by Libby and Seybert (2009), it was concluded that stock price and concerns about general reputation are the main drivers behind management' attempts to manipulate earnings. They further stated that other motives such as debt covenants, bonus compensation, and taxes play secondary roles in EM practices.

The central role of accounting accruals is to mitigate cash flow fluctuations so that net income reflects as accurately as possible the financial position of the company at year end (Dechow, 1994). Roychowdhury (2006) states that handling accruals is a convenient form of EM because it does not involve cash flows. Ronen and Yaari (2008) define accruals as non-monetary items that can be manipulated by management such as depreciation, inventories, receivables and payables.

EM literature considers that total accruals include normal accruals (non-discretionary ones) and accruals generated by EM practices (discretionary accruals). Non-discretionary accruals are expected accruals according to the firm's conditions, while discretionary accruals include distortions induced by the application of accounting rules or EM (Dechow, Meyers and Shakespeare, 2010). Kothari, Leone and Wasley (2005) state that discretionary accruals are synonymous with EM.

For the determination of total accruals (TA), the literature mentions two approaches: the cash flow method (where TA are the difference between the operating cash flow (CFO) and the operating income after tax) and the balance sheet method (TA results from variations in some balance sheet structures). The cash flow method has become more known since it has been shown that the other one can lead to measurement errors (Hribar and Collins, 2002). Thus, researchers can erroneously conclude that there is EM in the case of entities affected by mergers, acquisitions or discontinued operations, which have an impact on current assets and liabilities, but not on earnings.

While total accruals are calculated from financial statements, discretionary and non-discretionary accruals are not directly observable. Yoon and Miller (2002, p.399) state that a model is needed to separate the discretionary component from total accruals. There are several models developed, the Jones model and its modified versions being the milestone in the accruals approach.

Literature examines accrual EM in the context of some specific events or incentives, such as (Mostafa, 2017): maximizing management compensation, gaining import relief, avoiding anti-trust or debt covenants violations, etc. In Romania, EM literature is quite scarce. Matiş et al. (2010) argue that Jones model is the most significant EM model for the Romanian economic environment in terms of applicability. Brad et al. (2014) report a decrease in EM strategies in the year of the IFRS adoption by listed Romanian companies. Nechita (2015) does not find enough evidence to argue for EM through income smoothing strategies in the post IFRS adoption period. Nevertheless, the high negative connection between cash flows and items that do not impact cash, when IFRS are applied, might be a proof of EM as these items tend to decrease income volatility. 
Due to the lack of information regarding the aforementioned specific events and incentives for the Romanian market, this paper analyses the level and impact of EM in the context of the two reporting methods used for operating cash flows. The direct method works with information about cash receipts and payments corresponding to transactions occurring in the firm during a financial year. The indirect method reconciles from net income to net cash provided by operating activities. It involves some adjustments made to the accrual net income, referring to (Revsine, Collins and Johnson, 2008, p. 957): items included in net income that did not affect cash in the current period and items excluded from the accrual-basis income that did affect operating cash flows in the current period.

There is quite a strong debate about which reporting CFO method provides more useful information. On the one side, the direct cash flow reporting format leads to better prediction of future firm performance and has a stronger association with share prices (Bradbury, 2011). It also lowers information asymmetry and leads to higher quality reporting. Harrison and Horngren (2008, p. 280) consider that direct method provides clearer information about the sources and uses of cash. According to Mironiuc (2006), the direct method is favoured by investors because: it is the starting point in predicting future cash-flows used to determine the firm's value; it provides intelligible and objective information, presenting the facts without leaving room for subjective interpretations; it eliminates the effect of using different accounting treatments for the same transactions and events; it does not take into account operating revenues and expenses that are not cashrelated.

On the other side, it is argued that the purpose of the cash flow statement is to explain the difference between profits and operating cash flows, justifying the indirect approach (Bond, Bugeja and Czernkowski, 2012). Moreover, firms may prefer the indirect method if the use of the direct method discloses commercially sensitive information. According to Mironiuc (2006), it is easier to apply and preferred by managers who do not want to present to the external users the real picture of their business in terms of liquidity and solvability.

Even though the rules recommend the direct method, they allow for the indirect one to be used. Researchers have shown that when firms are provided with a choice between reporting formats for OCF, the vast majority of them typically use the indirect one (Clinch, Sidhu and $\operatorname{Sin}$ 2002). Romanian companies make no exception, as the majority use the indirect method. In the context of these two reporting methods, the paper aims at testing the following research hypothesis.

$H_{1}$ : There are EM practices at companies that determine their operational performance by using the indirect CFO reporting method.

Value relevance researchers believe that accounting information plays a key role in reflecting earnings or the economic value. Therefore, two major models exist: the price model and return model (Barth, Beaver and Landsman, 2001). According to the economic motivation of the research, these studies analyse: i) if a certain piece of accounting information is significantly related to equity market value - i.e. the price model or ii) how much of the change in equity market price is explained by accounting information - i.e. the return model.

As far as the impact of EM on value relevance is concerned, there are two flows of opinions in the literature (Jiraporn et al., 2008). One states the reduction of earnings quality in presence of opportunistic earnings handling (Lev, 1989). The other one argues for the opposite effect, if managers use earnings manipulation strategies to reflect more accurately the company performance.

Callao, Cimini and Jarne (2016) report a low value relevance of earnings of entities engaging in EM strategies. Nonetheless, the study shows an increase in usefulness of book value for entities using EM. Mostafa (2017) finds that earnings of firms involved in opportunistic EM techniques are less value relevant to investors who deem them less informative than the nonmanaged earnings. In Romania, Filip and Raffournier (2010) document a low quality of earnings reported by listed companies while Mironiuc and Huian (2016) show that other comprehensive income is value relevant.

In this context, considering discretionary accruals as a proxy that captures the existence of EM strategies and stock market price as a function of earnings and book value, we develop the following hypothesis:

$\mathrm{H}_{2}$ : Value relevance of accounting information is reduced in the presence of EM techniques at entities using the indirect CFO reporting method. 


\section{Research methodology}

\subsection{Operationalization of discretionary accruals}

To evaluate EM, there are several models of discretionary accruals determination. Using the Jones (1991) model, Kothari, Leone and Wasley (2005) introduce an additional control variable that deals with the effect of performance on discretionary accruals: lagged rate of return on asset (ROA) (see equation 1).

$$
\begin{aligned}
T A_{t} / A_{t-1}=\alpha_{0}+\alpha_{1} & \left(1 / A_{t-1}\right)+\alpha_{2}\left(\Delta R E V / A_{t-1}\right)+\alpha_{3}\left(P P E_{t} / A_{t-1}\right) \\
& +\alpha_{4} R O A_{t-1}+\varepsilon
\end{aligned}
$$

Where, $T A_{t}$ - total accruals in year $t ; A_{t-1}$ - lagged total assets; $\triangle R E V$ - change in revenues; $P P E_{t}$ property, plant and equipment; $\mathrm{ROA}_{\mathrm{t}-1}$ - lagged return on assets, $a_{0}$ - intercept, $a_{1}, a_{2}, a_{3}$ - regression coefficients; $\varepsilon$ residual.

This model is based on the understanding that working capital accruals are related to changes in revenues and depreciation is linked to assets. The coefficient of PPE is expected to be negative because these assets generate depreciation expense. The coefficient of the change in revenues should be positive (Ronen and Yaari, 2008). Return on assets (ROA) is one of the company's main profitability ratios, measuring the efficiency of asset utilization. The error term $(\varepsilon)$ represents the discretionary accruals (DA). The higher the DA are, the more evidence of EM exists.

\subsection{Value relevance of earnings and book value}

The model used to test the value relevance of accounting information in the presence of EM strategies is the one applied by Callao, Cimini and Jarne (2016). It is based on the Ohlson (1995) price model that is modified by adding to the original variables a proxy for EM, DA, which shows the level of discretionary accruals. Moreover, the net income and book value are interacted with a dummy variable for the use of EM (see equation 2).

$$
\begin{gathered}
P_{i t}=\alpha_{0}+\alpha_{1} E P S_{i t}+\alpha_{2} d D A_{i t} \times E P S_{i t}+\alpha_{3} B V_{i t}+\alpha_{4} d D A x \\
B V_{i t}+a_{5} D A_{i t}+\varepsilon_{i t}
\end{gathered}
$$

Where, $\mathrm{P}_{\mathrm{it}}$ - stock market price of the firm i, 3 months after annual financial statements are released for year $t$; EPS - earnings per share; $\mathrm{dDA}$ - a dummy variable that takes the value 1 if the company has high levels of discretionary accruals, i.e. use the indirect CFO method; BV - book value per share; DA - discretionary accruals (residuals of the Kothari, Leone and Wasley, 2005, model).

$\mathrm{H}_{2}$ is validated if the sum of the regression coefficients $\left(\alpha_{1}+\alpha_{2}\right)$ is lower and statistically different than the regression coefficient for earnings $\left(\alpha_{1}\right)$ reported by companies using the direct CFO method. According to Callao, Cimini and Jarne (2016), if value relevance of earnings decreases, investors put more weight on book value, due to the stock market value being a convex function of earnings and book value. So $\mathrm{H}_{2}$ is fully validated if the sum of the regression coefficients $\left(\alpha_{3}+\right.$ $\alpha_{4}$ ) is higher than the regression coefficient for book value $\left(\alpha_{3}\right)$ reported by companies using the direct CFO method.

\section{Data, sample and descriptive statistics}

Sample consists of all Romanian listed companies on the Bucharest Stock Exchange for a 10 year span: 20062015. Financial firms are excluded due to their different operations and regulations. Accounting data used to compute all study variables are extracted from the annual financial statements compiled by the Thomson Reuters Eikon database. The initial sample included 980 observations coming from 67 companies. After the eliminations of observations with incomplete data, 556 firm-year observations (from 65 companies) remained.

Based on the statement of cash flows, the CFO reporting method used is identified, which results in a number of 255 observations using the direct method (46\% of all observations), whereas 301 apply the indirect method (54\%). This confirms the findings of Istrate (2015) that Romanian companies use the direct method much more than entities from other European countries. In some Western European countries, the indirect method is used by approximately $80-90 \%$ of entities (Kvaal and Nobes, 2010). Therefore, the sample is divided into two sub-samples, one called DIR for the observations reported according to the direct method, the other one called INDIR. 
To analyse the two sub-samples in terms of performance, we calculate three important indicators. As a measure of operational performance (Yoon and Miller, 2002), cash flows from operations over lagged total assets are used. Earnings per share (EPS) and return on assets (ROA) as indicators of stock market performance and profitability are used to show performance based on accrual earnings. Table no. 1 provides descriptive statistics. It is noticeable that in the case of the INDIR sample, both the cash-based and accrual-based performance are, on average, higher than for the DIR sample.

\begin{tabular}{|c|c|c|c|c|c|}
\hline Variables & Mean & Median & Std. Deviation & Minimum & Maximum \\
\hline \multicolumn{6}{|c|}{ Direct CFO Method $\quad N=255$} \\
\hline ROA & 0.0320 & 0.0349 & 0.1399 & -1.102 & 0.8268 \\
\hline EPS & 0.1158 & 0.0142 & 2.6392 & -13.5204 & 31.7545 \\
\hline Cash flows from operations & -0.0235 & 0.0006 & 0.0709 & -0.3791 & 0.0399 \\
\hline \multicolumn{6}{|c|}{ Indirect CFO Method $\quad N=301$} \\
\hline ROA & 0.0793 & 0.0678 & 0.0903 & -0.6468 & 0.538 \\
\hline EPS & 1.4691 & 0.0479 & 5.5357 & -10.5065 & 42.6807 \\
\hline Cash flows from operations & 0.1228 & 0.0982 & 0.0960 & 0.0400 & 0.9304 \\
\hline \multicolumn{6}{|c|}{ Entire sample } \\
\hline ROA & 0.0576 & 0.0550 & 0.1180 & -1.1020 & 0.8268 \\
\hline EPS & 0.8484 & 0.0297 & 4.4953 & -13.5204 & 42.6807 \\
\hline Cash flows from operations & 0.0557 & 0.0451 & 0.1123 & -0.3791 & 0.9304 \\
\hline
\end{tabular}

ROA is return on assets; EPS is earnings per share; Cash flows from operations is deflated by total assets; $N$ is the number of firm-year observations for the two sub-samples and the entire sample

Source: Authors' projections

This makes us attempt to determine whether EM techniques could be one of the factors that might explain the superior level of performance for companies using the indirect method. In other words, we test whether the firms in the INDIR sample are more engaged in EM procedures, by using accounting options that increase their earnings, than those in the DIR sample.

\section{Empirical results}

\subsection{Earnings Management}

Table no. 2 shows total accruals and discretionary accruals for both sub-samples and the whole sample. Discretionary accruals are the residuals resulting of model described in equation (1).

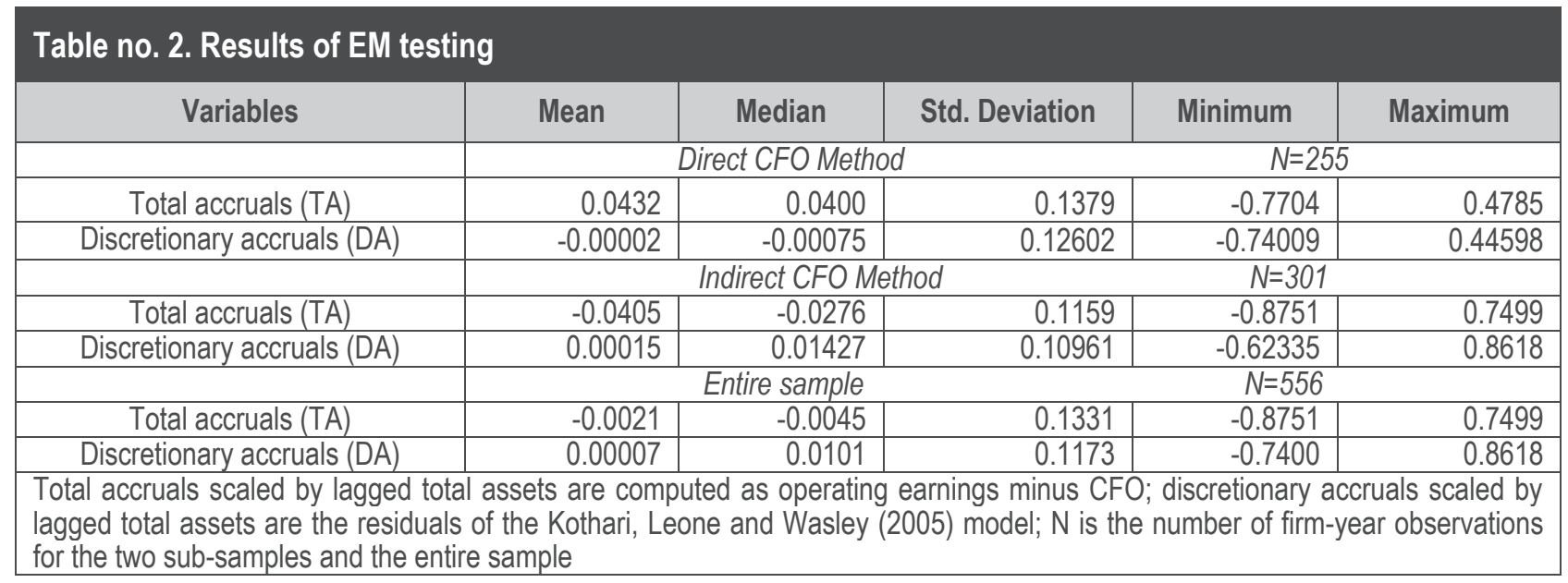

Source: Authors' projections 
Observations prepared under the direct method have a positive mean accrual of 0.0432 whereas those using the indirect method have a negative mean total accruals. But the variable that shows the level of EM is discretionary accruals (DA). The mean values of DA follow a different pattern than total accruals. Table no. 2 shows that observations from the INDIR sample produce the highest level of discretionary accruals. This means the positive mean DA value indicates evidence of attempts to opportunistically increase earnings. The opposite situation is noticeable at companies using the direct CFO method that have a mean negative value for DA.

$\mathrm{H}_{1}$ is validated. Results confirm that companies applying the indirect CFO reporting method are more tempted to use earning-increasing techniques that might explain their overall better performance in terms of cash flows and accrual accounting income.

\subsection{Value relevance testing}

Table no. 3 shows some surprising results. Value relevance of earnings reported by companies from the DIR sample is lower $\left(a_{1}=2.062\right)$ than that of companies using the indirect CFO method (sum of $a_{1}+a_{2}=3.305$ ). This means, according to the price model, that investors find earnings of entities that manipulate them more useful for their decisionmaking. This contradicts findings of Mostafa (2017) and Callao, Cimini and Jarne (2016). Nevertheless, it confirms results of Hunton, Libby and Mazza (2006) who argue that in less transparent settings (which is the case of the indirect CFO method) EM strategies are not obvious to investors. Moreover, these strategies improve stock market prices and do not alter management's reputation in terms of financial reporting.

\section{Table no. 3. Results for value relevance testing}

\begin{tabular}{|c|c|c|c|}
\hline Variables & Coefficient & T-statistic & P-value \\
\hline Constant & 1.235 & 1.741 & 0.082 \\
\hline EPS & 2.062 & 5.068 & 0.000 \\
\hline $\mathrm{dDA}_{\text {itt }} \mathrm{XEPS}$ it & 1.243 & 2.136 & 0.033 \\
\hline $\mathrm{BV}_{\text {it }}$ & 0.425 & 6.554 & 0.000 \\
\hline $\mathrm{dDA}_{\mathrm{it}} \mathrm{xBV_{it }}$ & -0.107 & -1.355 & 0.176 \\
\hline DA $A_{i t}$ & -9.999 & -1.688 & 0.092 \\
\hline $\mathrm{R}^{2}=0.727$ & F-statistic $=292.405(p-$ & & \\
\hline
\end{tabular}

$\mathrm{P}_{\mathrm{it}}$ is stock market price of the firm $i$, measured 3 months after annual financial statements are released for year $t$; EPS is earnings per share; $\mathrm{dDA}$ is a dummy variable controlling for the levels of discretionary accruals; BV is book value per share; DA is discretionary accruals calculated with the Kothari, Leone and Wasley (2005) model

Source: Authors' projections

Due to the convexity of the function describing the relationship between market price, earnings and book value (Callao, Cimini and Jarne, 2016), results of the model show a transfer of explanatory power from book value to earnings. That is, when earnings have a high value relevance, investors tend to place less weight on book value. This is shown by the fact that, for the INDIR sample, sum of $a_{3}+a_{4}=0.318$ is lower than the coefficient displayed by the DIR sample $\left(\alpha_{3}=0.425\right)$. This means that EM practices are associated with less useful information regarding book value. It is worth mentioning that DA is statistically significant only at $10 \%$ which shows investors rather ignore the EM attempts.
As the overall usefulness of accounting information in the determination of stock prices increases in presence of EM strategies, $\mathrm{H}_{2}$ is not validated.

\section{Bonclusions}

This paper analyses the association between EM and the value relevance of accounting information for a sample of 556 observations from 65 companies listed on the Bucharest Stock Exchange during 2006-2015. The authors firstly test whether firms using the indirect method in determining operational cash flows (which also report higher performance) are more prone to earnings growth strategies than companies using the 
direct method (that have lower performance). After confirming that companies applying the indirect method are tempted to adopt EM strategies (which generate higher performance), the authors assess whether the association between stock market prices and accounting figures is changed by the opportunistic behaviour of these firms.

Findings show that discretionary accruals are positive and significantly higher for firms using the indirect CFO method than for firms that apply the direct method. These results indicate that companies with high operational performance generated by the indirect method use more EM practices to expedite their earnings and mislead investors. However, results show that regression coefficients are higher for the earnings of entities using the indirect CFO reporting method. This suggests that because of the lower transparency of the information provided by the indirect method, investors do not observe manipulative practices and do not penalize managers who show an opportunistic behavior to increase earnings. In other words, earnings of companies that have achieved both operational and market performance or high profitability, due to the opportunistic EM strategies they are involved in, have a higher value relevance than firms providing more transparent CFO information (by using the direct method). Managers of these companies escape with unaltered reputation in terms of financial reporting integrity. Moreover, the discretionary accruals information that captures the level of EM is not, according to the results, a predictor that investors take into account when assessing the value of listed companies.

These findings are relevant to investors who should pay attention to the CFO reporting method that might explain to some extent the reported performance level. They should penalize managers and firms that use the indirect method as an EM technique.

Limitations of the paper refer to the small number of observations used, which is a common problem among studies investigating emergent economies such as Romania and the lack of analysis of specific incentives or events that could shed some light on the reasons behind the opportunistic EM behaviour.

\section{REFERENCES}

1. Barth, M.E., Beaver W.R. and Landsman, R. (2001), The relevance of the value relevance literature for financial accounting standard setting: another view, Journal of Accounting and Economics, vol. 31, no. 1-3, pp. 77-104, DOI 10.1016/s0165-4101(01)00019-2.

2. Beneish, M.D. (2001), Earnings management: a perspective, Managerial Finance. [Online], vol. 27, no. 12, Accessed April 10, 2017, https://www.researchgate.net/publication 1228306697_Earnings_Management_A_Perspectiv e, DOI 10.2139/ssrn.269625.

3. Bond, D., Bugeja, M. and Czernkowski, R. (2012), Did Australian firms choose to switch to reporting qperating cash flows using the indirect method?, Wiley-Blackwell Publishing Asia, vol. 22, no. 1, pp. 18-24, DOI 10.1111/j.1835-2561.2011.00156.x.

4. Brad, L., Dobre, F., Turlea, C. and Braşoveanu, I.V. (2014), The impact of IFRS adoption in Romania upon the earnings management of the
Bucharest Stock Exchange Entities, Procedia Economics and Finance, vol. 15, pp. 871-876, DOI 10.1016/s2212-5671(14)00550-4.

5. Bradbury, M. (2011), Direct or indirect cash flow statements?, Australian Accounting Review, vol. 57, no. 21, pp. 124-130, DOI 10.1111/j.18352561.2011.00130.x.

6. Callao, S., Cimini, R. and Jarne, J.I. (2016), Value relevance of accounting figures in presence of EM. Are enforcement and ownership diffusion really enough?, Journal of Business Economics and Management, vol. 17, no. 6, pp. 1286-1299, DOI 10.3846/16111699.2016.1203816.

7. Clinch, G., Sidhu, B. and Sin, S. (2002), The usefulness of direct and indirect cash flow disclosures, Review of Accounting Studies, vol. 7 , no. 4, pp. 383-404, DOI 10.2139/ssrn.251957.

8. Dechow, P. (1994), Accounting earnings and cash flows as measures of firm performance: The role of accounting accruals, Journal of Accounting and 
Economics, vol. 18, no. 1, pp. 3-42, DOI 10.1016/0165-4101(94)90016-7.

9. Dechow, P., Meyers, L. and Shakespeare, C. (2010), Fair value accounting and gains from asset securitizations: A convenient EM tool with compensation side-benefits, Journal of Accounting and Economics, vol. 49, no. 1, pp. 2-25, DOI 10.1016/j.jacceco.2009.09.006.

10. Filip, A. and Raffournier, B. (2010), The value relevance of earnings in a transition cconomy: the case of Romania, The International Journal of Accounting, vol. 45, no. 1, pp. 77-103, DOI 10.1016/j.intacc.2010.01.004.

11. Gunny, K. (2010), The relation between EM using real activities manipulation and future performance: evidence from meeting earnings benchmarks, Contemporary Accounting Research, vol. 27, no. 3, pp. 855-888, DOI 10.1111/j.19113846.2010.01029.x.

12. Harrison, W.T. and Horngren, C.T. (2008), Financial Accounting, $7^{\text {th }}$ edition, Pearson.

13. Healy, P.M. and Wahlen, J.M. (1999), A review of the EM literature and its implications for standard setting, Accounting Horizons, vol. 13, no. 4, pp. 365-383, DOI 10.2139/ssrn.156445.

14. Hribar, P. and Collins, DW. (2002), Errors in estimating accruals: implications for empirical research, Journal of Accounting Research, vol. 40, no. 1, pp. 105-134, DOI 10.1111/1475679x.00041.

15. Hunton, J., Libby, R. and Mazza, C. (2006), Financial reporting transparency and earnings management, The Accounting Review, vol. 81, no. 1, pp. 135-157, DOI 10.2308/accr.2006.81.1.135.

16. Istrate, C. (2015), The persistence of the accounting policies after the transition to IFRS of the Romanian listed companies, Accounting and Management Information Systems, vol. 14, no. 4, pp. 599-626.

17. Jiraporn, P., Miller, G., Yoon, S. and Kim, Y. (2008), Is EM opportunistic or beneficial? An agency theory perspective, International Review of Financial Analysis, vol. 17, no. 3, pp. 622-634, DOI 10.1016/j.irfa.2006.10.005.

18. Jones, J.J. (1991), Earnings management during import relief investigations, Journal of Accounting
Research, vol. 29, no. 2, pp. 193-228, DOI $10.2307 / 2491047$.

19. Kothari, S.P., Leone, A.J. and Wasley, C.E. (2005), Performance-matched discretionary accrual measures, Journal of Accounting and Economics, vol. 39, no. 1, pp. 163-197, DOI 10.1016/j.jacceco.2004.11.002.

20. Kvaal, E. and Nobes, C. (2010), International differences in IFRS policy choice: a research note, Accounting and Business Research, vol. 40, no. 2, pp. 173-187, DOI 10.1080/00014788.2010.9663390.

21. Lev, B. (1989), On the usefulness of earnings and earnings research: lessons and directions from two decades of empirical research, Journal of Accounting Research, vol. 27, no. 1, pp. 153-192, DOI 10.2307/2491071.

22. Libby, S. and Seybert, N. (2009), Behavioral studies of the effect of regulation on EM and accounting choice, Johnson School Research Paper Series, vol.16-09, pp. 1-38, DOI 10.1093/acprof:oso/9780199546350.003.0013.

23. Matiş, D., Vladu, A,B., Negrea, L. and Sucala, L. (2010), Jones, Dechow and Kasznik models significance in the Romanian economic environment, Annales Universitatis Apulensis Series Oeconomica, vol. 12, no. 1, pp. 253-266.

24. Mironiuc, M. (2006), Informational valences of the cash flow statement - methodological and interpretative approaches, [Online]. Accessed April 1, 2017, https://ssrn.com/abstract=980736, DOI: 10.2139/ssrn.980736.

25. Mironiuc, M. and Huian, M.C. (2016), Study of the congruence between accounting numbers and stock market variables through comprehensive income: empirical evidence for Romanian companies quoted on the regulated market, Journal of Accounting and Management Information Systems, vol. 15, no. 3, pp. 498-521.

26. Mostafa, W. (2017), The impact of earnings management on the value relevance of earnings. Empirical evidence from Egypt, Managerial Auditing Journal, vol. 32, no. 1, pp. 50-74, DOI 10.1108/maj-01-2016-1304.

27. Nechita, E. (2015), Earnings management and quality of financial reporting: a pre-post IFRS 
adoption comparative analysis for companies listed on the Bucharest Stock Exchange, Audit Financiar, vol.13, no. 122, pp. 74-84.

28. Obigbemi, I.F., Omolehinwa, E.O., Mukoro, D.O., Ben-Caleb, E. and Olusanmi, O.A. (2016),

Earnings management and board structure: evidence from Nigeria, SAGE Open, JulySeptember, pp. 1-15, 10.1177/2158244016667992.

29. Revsine, L., Collins, D. and Johnson, B. (2008), Financial reporting and analysis, $3^{\text {rd }}$ edition, Pearson.

30. Ronnen, J. and Yaari, V. (2008), Earnings management. Emerging insights in theory, practice, and research, Springer, New York,10.1007/s10997-009-9111-z.
31. Roychowdhury, S. (2006), Earnings management through real activities manipulation, Journal of Accounting and Economics, vol. 42, no. 3, pp. 335370, DOI 10.1016/j.jacceco.2006.01.002.

32. Vladu, AB., Amat, O. and Cuzdriorean, DD. (2014), Truthfulness in accounting: how to discriminate accounting manipulators from non-manipulators, Economics Working Papers 1434, Universitat Pompeu Fabra, pp. 1-44, DOI 10.1007/s10551016-3048-3.

33. Yoon, S.S. and Miller, G.A. (2002), Cash from operations and earnings management in Korea, The International Journal of Accounting, vol. 37, no. 4, pp. 395-412, DOI 10.1016/s00207063(02)00193-0. 